\title{
Pattern of hematological malignancy in a tertiary level hospital in Kathmandu
}

\author{
Amar Narayan Shrestha ${ }^{1}$, Sunil Kumar Singh ${ }^{1}$, Rajiv Kumar Deo ${ }^{2}$, Rinku \\ Joshi $^{2}$, Ayusha Poudel ${ }^{3}$, Barun Babu Aryal ${ }^{3}$, Anurag Adhikari ${ }^{3}$ \\ ${ }^{I}$ Department of Pathology, Shree Birendra Hospital, Kathmandu, Nepal \\ ${ }^{2}$ Department of Medicine, Shree Birendra Hospital, Kathmandu, Nepal \\ ${ }^{3}$ Shree Birendra Hospital, Kathmandu, Nepal
}

\section{Keywords: \\ Hematology; \\ Lymphoma; \\ Leukemia; \\ Malignancy;}

\begin{abstract}
Background: Hematological malignancies involve the blood elements, marrow, lymph and lymphatic elements and are among the common malignancies afflicting the human race. They tend to involve the extremes of the ages- the young and the elderly.
\end{abstract}

Materials and Methods: A hospital register based retrospective study was conducted including the data of five years duration. The confirmation of diagnosis was done with blood smear examination, bone marrow examination and flow-cytometry. The epidemiological parameters were then calculated using Microsoft Excel and SPSS.

Results: Among the total number of cases, $60.7 \%$ were males and $39.3 \%$ were females. Age group of 50 to 59 years was most commonly involved. Lymphoma (including Hodgkin's and non-Hodgkin's) was the most common hematological malignancy.

Conclusion: Males are more afflicted by hematological malignancies and lymphoma was the commonest hematological malignancy.

\section{Correspondence:}

Dr. Amar Narayan Shrestha, $M D$

Assistant Professor

Department of Pathology, Shree Birendra Hospital, Kathmandu, Nepal ORCID: 0000-0003-4300-4223

Email ID: shresthaaamar@gmail.com

Received : November 21 $1^{\text {st }} 2018$; Accepted : March 14 $4^{\text {th }} 2019 ;$ Published : March $29^{\text {th }} 2019$

Citation: Shrestha AN, Singh SK, Deo RK et al. Pattern of hematological malignancy in a tertiary level hospital in Kathmandu. J Pathol Nep 2019;9:1457-9. DOI 10.3126/jpn.v9i1.23355

Copyright: This is an open-access article distributed under the terms of the Creative Commons Attribution 4.0 International License, which permits unrestricted use, distribution, and reproduction in any medium, provided the original author and source are credited.

\section{INTRODUCTION}

Hematopoietic malignancies include tumors that affect the blood, bone marrow, lymph, and lymphatic system. ${ }^{1}$ Leukemia is malignant neoplasm of the hematopoietic stem cells characterized by diffuse replacement of the bone marrow and/or peripheral blood by neoplastic cells. ${ }^{2}$ Leukemia was identified as a separate malignancy in 1889. ${ }^{3}$ The hematological malignancies are more common in the developed countries as compared to the developing countries. Peripheral blood smear examination is a means to suggest a range of diagnoses or likely diagnosis., 4,5 The first step in the diagnosis of leukemia involves peripheral blood smear which involves morphological examination of blood elements. The morphological study of the blood 
elements provides a peek into the functional status of the bone marrow. Sometimes, study of peripheral blood smear alone is sufficient to establish the diagnosis but at other times, it can be later confirmed by genotypic studies of the specimen. $^{6}$

\section{MATERIALS AND METHODS}

This retrospective descriptive study was conducted in a tertiary care hospital in Kathmandu using hospital records. All diagnosed cases of hematological malignancies from Baisakh $1^{\text {st }} 2070$ to Chaitra $31^{\text {st }} 2074$ were included in the study. Permission to study was obtained from institutional review committee. The hospital pathology and oncology section register was used for this purpose, and once hematological malignancy was identified, the patient records were accessed and used for analysis. The definite diagnosis of the patients prior to inclusion in the registry was done with peripheral blood smear and bone marrow examination and supplemented by flow cytometry. Anonymity of the patients were ensured at all times. The cases with ambiguous diagnosis and those with incomplete demographic data were excluded from the study. Simple univariate and multivariate analysis was done using Microsoft excel 2016 and SPSS v 25 to calculate age and sex distribution of hematological malignancies, and further subdivision of the malignancies was done whenever possible.

\section{RESULTS}

During the study period, a total of 163 hematological malignancies were included in our study. Sixty four $(39.3 \%)$ of them were female and 99 (60.7\%) were male with slight male predominance with male to female ratio of 1.54:1. The age range included in our study was from 2 years to 99 years. The most common age group was 50 to 59 years $(22.1 \%)$, followed by 60 to 69 years $(21.5 \%)$, and 70 to 79 years $(13.5 \%)$. There were $78(47.8 \%)$ cases of leukemias, $67(41.1 \%)$ cases of lymphomas and $18(11 \%)$ cases of multiple myeloma.

Among cases of leukemia, there were 26 cases $(15.9 \%)$ of chronic leukemias of which 9 cases $(5.5 \%)$ were of chronic leukoctyic leukemia and $17(10.4 \%)$ cases of chronic myeloid leukemia. Among 52 (31.9\%) cases of acute leukemia, $22(13.5 \%)$ cases were of acute lymphoblastic leukemia, $22(13.5 \%)$ cases of acute myelogenous leukemia. In 8 cases of aucte leukemia, contact with the patient was lost. Among lymphomas, 54 (33.1\%) were cases of NonHodgkin lymphoma and 13 (7.9\%) of Hodgkin Lymphoma.

Out of 52 total cases of acute leukemia, 34 (65.4\%) were male and 18 (34.6) were female. The highest incidence was found in the age group of 50 to $59(n=11 ; 21.1 \%)$ followed by age group of less than 10 years of age $(n=8 ; 15.4 \%)$. Out of 26 cases chronic Leukemia, $18(69.2 \%)$ were male and 8 $(30.8 \%)$ were female. The greatest burden was seen in age group 40 to $49(7,26.9 \%)$ followed by age groups 60 to 69 and 70 to $70(5,19.2 \%)$ each.

A total of 67 lymphoma cases were diagnosed out of which $36(53.7 \%)$ were male and 31 (46.3) female. The highest incidence was seen among age group 60 to $69(18,26.9 \%)$ followed by age group 50 to $59(16,23.9 \%)$. Among the total of 18 diagnosed case of multiple myeloma, $11(61.1 \%)$ were male and 7 (38.9\%) female. The most cases were from among age group 60 to $69(9,50 \%)$ followed closely by age group 50 to $59(7,38.9 \%)$.

\section{DISCUSSION}

Hematological malignancies were observed in $39.3 \%$ of female $60.7 \%$ of male. A study conducted in a tertiary level hospital in Eastern Region of Nepal found the M: F ratio as 1.8:1.2 Similarly, another study in the same region calculated the patients as $54 \%$ males and $46 \%$ females. $^{7}$ Similar findings were observed in other studies. ${ }^{8,9}$

Our study included age group from 2 to 99 years. A study in Eastern region included age range from 2 to 90 years with mean age of 37.6 years $^{7}$ while another study in the same region had age range from 11 days to 81 years. $^{2}$

Leukemias were found to be the most common hematological malignancy. This is supported by a study in Yemen which found that leukemia was the most common diagnosis on bone marrow examination. ${ }^{10}$ Acute leukemia was more common than chronic leukemia in our study as well as the one in India9 Among lymphomas, Non-Hodgkin's lymphoma was more common than Hodgkin's Lymphoma. This is supported by the fact that it was found to be the third most common malignancy in Nepal. ${ }^{11}$ Multiple myeloma comprised of $10 \%$ of the hematological malignancies. A study in India has reported that multiple myeloma in younger individuals is commoner than in the West. ${ }^{12}$

Acute Leukemia: Though majority of leukemia occur in older people, it is the commonest malignancy in children and adolescents. ${ }^{13}$ Among 52 cases of acute leukemia, $15.4 \%$ was found in age group of less than 10 years. It is similar to the burden found in a study in Nepal which had a burden of $21 \%{ }^{14}$

Chronic Leukemia: The burden of chronic leukemia in our study was $15.9 \%$. It is much less than that reported in a study in Eastern Nepal i.e. $38.26 \%{ }^{2}$ and 26.91 percent. $^{7}$

Lymphoma: In our study the incidence of lymphoma was $49.3 \%$. It is much higher than reported in India in a study i.e. 14.85 percent. $^{9}$ and contrary to the finding of study in India $^{12}$ that lymphoma are highest in United States, Europe and Australia and lowest in Asia.

Multiple Myeloma: It constitutes of about $15 \%$ of all 
hematological malignancies, ${ }^{15}$ in our study it comprised of $11 \%$ of all cases. The incidence between male and female is found to be similar in few studies ${ }^{16}$ but similar to another study in $\mathrm{Nepal}^{14}$, we found the burden more in male $(61.1 \%)$ compared to female $(38.9 \%)$.

\section{CONCLUSION}

Males are more afflicted by hematological malignancies and lymphoma was the commonest hematological malignancy.

\section{Conflict of Interest: None}

\section{REFERENCES}

1. Vardiman JW, Thiele J, Arber DA, et al. The 2008 revision of the World Health Organization (WHO) classification of myeloid neoplasms and acute leukemia: rationale and important changes. Blood. 2009;114:937-51. Crossref

2. Shrestha KR, Sah SP. Pattern of Occurrence of Leukemia at a Teaching Hospital in Eastern Region of Nepal - A Six Year Study J Nepal Med Assoc 2009;48:35-40. Crossref

3. Ebstein W: Uber die acute leukemie and pseudoleukamie. Dtsch Arch Klin Med 1889;44: 343.

4. Stewart BW, Wild CP. World Cancer Report 2014. International Agency for Research on Cancer. International Agency for Research on Cancer; 2014. 630p. ISBN 9283204298

5. Bain BJ. Diagnosis from the Blood Smear. N Engl J Med 2005; 353 : 498-507 Crossref

6. Abdulsalam A. Laboratory diagnosis of acute leukemia in Iraq, the available options. Turkish Journal of Hematology 2010; 27: 320-1. Crossref

7. Paudyal P, Pradhan A, Pokharel S, Shah N, Pradhan B, Poudel P. Pattern of hematological malignancies diagnosed by peripheral smear examination. Journal of BP Koirala Institute of Health Sciences [Internet]. 2018;1:25-35. Crossref
8. Weldetsadik AT. Clinical characteristics of patients with hematological malignancies at Gondar university hospital, North West Ethiopia. Ethiop Med J 2013;51:25-31. Crossref

9. Kusum A, Negi G, Gaur DS, et al. Hematological malignancies diagnosed by bone marrow examination in a tertiary hospital at Uttarakhand, India. Indian Journal of Hematology \& Blood Transfusion. 2008;24:7-11. Crossref

10. Al Ghazaly J, Al Selwi AH, Abdullah M, Al-Jahafi AK, Al-Dubai W, Al-Hashdi A. Pattern of Hematological diseases diagnosed by bone marrow examination in Yemen: a developing country experience. Clin Lab Haematol 2006;28:376-81. $\underline{\text { Crossref }}$

11. Bajracharya N, Karki P, Sapkota S, Bastakoti S, Yagol N, Khan G, et al. Prevalence pattern of cancer and handling of cytotoxic drugs. Kathmandu Univ J Sci Eng Technol. 2006;2:1-7

12. Bhutani M, Vora A, Kumar L, Kochupillai V (2002) Lymphohemopoietic malignancies in India. Medical Oncology 2002;19:141-50. Crossref

13. Xie Y, Davies SM, Xiang Y, Robison LL, Ross JA. Trends in leukemia incidence and survival in the United States (1973-1998). Cancer 2003;97:2229-35. Crossref

14. Ghartimagar D, Ghosh A, Narsimhan R, Talwar OP. Patterns of hematological and non-hematological malignancies in bone marrow in a tertiary care hospital in Nepal - 11 years study. Nepal Med Coll J 2012;14:187-92. Crossref

15. Devesa SS, Silverman DT, Young JL Jr et al. Cancer incidence and mortality trends among whites in the United States. J Natl Cancer Inst 1987;79:701-70 Crossref

16. Grogan TM, Muller- Hermelink HK, Camp BV, Harris NL, Kyle RA. Plasma cell neoplasms. In: Jaffe ES, Harris NL, Stein H, Vardiaman JW, editors. Pathology and genetics of tumors of hemoatopoietic and lymphoid tissues. Lyon: IARC press; 2001.pp142-56. 